\title{
The Effect of Rubbish Management Socialization Based on Indonesian Ulama Council'S Fatwa Number 47 of 2014 on Community Behavior in Dealing with Rubbish Problem
}

\author{
Azis Muslim ${ }^{1}$ \\ ${ }^{1}$ Dakwah and Communication of Sunan Kalijaga State Islamic University, Yogyakarta, Indonesia \\ Correspondence: Azis Muslim, Dakwah and Communication of Sunan Kalijaga State Islamic University, \\ Yogyakarta, Indonesia. E-mail: muslimtenan@gmail.com
}

Received: July 27, 2017

doi:10.5539/ass.v13n10p55
Accepted: August 30, $2017 \quad$ Online Published: September 28, 2017

URL: https://doi.org/10.5539/ass.v13n10p55

\begin{abstract}
Rubbish has been an acute and less resolvable problem, because the volume of rubbish produced by human being increases over years. Many attempts have been taken to solve this problem, one of which is through the economic value-based socialization of rubbish management. However, the result has not been able to generate consciousness and to change the community behavior collectively in dealing with rubbish problem. This research studied another attempt taken to deal with rubbish problem, the socialization of rubbish management using economic and religion value combination. This research was conducted in Sleman Regency. Data was collected through interview, observation, and documentation. Analysis was conducted interactively. The result of research showed that the socialization of rubbish management based on the Indonesian Ulama Council's Fatwa Number 47 of 2014 could build consciousness and change the community behavior collectively in dealing with rubbish problem, when the participants selected reflected on the representativeness of all community elements, the presence of volunteers from the community who were willing to organize, the participants were given information completely about the objective of socialization, government's support to the community conducting rubbish management activity, and the material of socialization was taken for granted by the participants of socialization.
\end{abstract}

Keywords: rubbish management socialization, rubbish coping behavior, Indonesian Ulama Council's Fatwa Number 47 of 2014

\section{Introduction}

Rubbish is the unusable residual product of human activity (Muslim, 2015). Over years, the volume of rubbish produced by the world's population increases with the increase in population number. In Thailand, for example, rubbish volume reaches 30.640 ton per day in 1993. This figure increases to 41.410 ton per day in 2009 (Ittiravivongs, 2012). Meanwhile, the volume of rubbish produced by Indonesian people reaches about 0.5 $\mathrm{kg} /$ head/day in 1994. In 2000, this figure reaches $1 \mathrm{~kg} / \mathrm{head} /$ day, and in 2020 it is expected to increase to 2.1 $\mathrm{kg} /$ head/day (Chaesfa \& Pandjaitan, 2013). It means that, with the estimation about Indonesian population number of 271 millions people in 2020, the volume of rubbish to be produced is 569,100 ton per day. This condition of course needs serious management from government, private and society.

The failure of rubbish problem resolution impacts not only on environment problem but also on social problem. The community's declination against the existence of final rubbish disposal is the concrete example of social problem occurring due to the failure of rubbish problem management. Rubbish is actually not a "repugnant" thing. Rubbish can have economic value, when it is managed correctly. Therefore, Republic of Indonesia's Law Number 18 of 2008 about Rubbish Management mentions that rubbish should be considered as a resource with economic value and utilized as useful thing.

The reality shows that many people burn and or dispose rubbish into river or in the edge of street (Yudistira, 2013). They do not realize that their deed can harm their and other's security (Muslim, 2015). Ironically, those doing it are not only the ones not knowing rubbish management technique, but also those who have understood and ever acquired education about technique of managing rubbish correctly. They take shortcut by burning or disposing rubbish because economically the income obtained from rubbish processing and management is not 
comparable to the energy exerted.

It is confirmed by Mulasari (2012) finding no significant correlation between knowledge and rubbish managing behavior. The finding of her study conducted in Dukuh Hamlet, Sidokarto Village, Godean Sub District, Sleman Regency Yogyakarta, showed that $92.2 \%$ out of 77 respondents state that they have knowledge on how to process the rubbish well. Meanwhile, only $45.5 \%$ or 35 respondents have good rubbish managing behavior.

Changing the community's paradigm about the existence of rubbish is not easy. Various forms of socialization about rubbish management with economic value approach has been done, by either government or NGOs caring about environment, but the result has not shown the massive success. Therefore, there should be a method of socializing rubbish management not only emphasizing on economic value but also combined with other values, such as religion values.

The combination of economic and religion values in rubbish management socialization material is expected to be fruitful. It is because firstly, the implementation of religion tenet is an obligation for each individual. It means that when managing rubbish is an obligation, every individual doing worship obediently will implement the tenet. Secondly, misperception in treating the existence of rubbish, such as perceiving rubbish as repugnant thing that should be disposed or removed from house environment is affected by the narrow understanding on religious values. Islam, for example, emphasizes strongly on the importance of cleanliness and beauty. It means not only clean and beautiful individual, but also clean and beautiful environment. Islam prohibits its communities to use others' goods without permission. If it is conceived broadly, disposing rubbish into other field (garden) without permission is prohibited as well. Thirdly, managing rubbish will result in two advantages: economic and worship.

One of rubbish managements that has combined economic and religious values in socializing the rubbish management is Pengelola Sampah Mandiri (PSM) "Permata" (Permata Independent Rubbish Management). PSM "Permata" always includes the Indonesian Ulama Council's Fatwa (Fatwa MUI) Number 47 of 2014 into rubbish management in conducting its socialization. This Fatwa MUI is the main foundation to "frighten" the community in order to be willing to manage rubbish, because the decision in such the fatwa clearly emphasizes on individual Muslims' obligation of managing rubbish from their own activity residue, prohibiting or proscribing the haphazardly rubbish disposal, and obliging those capable of processing rubbish to recycle the rubbish into some goods useful to improve their life wellbeing.

PSM "Permata" is a non-government organization caring about environment. This institution located in Pakem Tamanmartani Kalasan Sleman Daerah Istimewa Yogyakarta. This institution established in 2012 is trusted by Living Environment Agency of Sleman Regency to socialize the rubbish management, particularly for those living in Sleman Regency area.

Considering the background above, it is interesting to study the successfulness of PSM "Permata" in undertaking rubbish management socialization. In the author's knowledge, no study has discussed this problem. Some studies found discussed the socialization of rubbish management from its economic values (Nugraha et al., 2007; Nuzuli et al., 2015; Setyowati, 2015; Riyadi, 2015). This research limits its focus of study on the effect of rubbish management socialization based on Fatwa MUI Number 47 of 2014 on community behavior in dealing with rubbish problem.

\section{Review of Literature}

Islam is a religion caring about cleanliness. Islam instructs its adherents to maintain cleanliness. It is as indicated with hadits of Prophet Muhammad SAW stating that "cleanliness is a part of faith" (Nawawi, 2007). The cleanliness intended in this hadits not only pertains to body but also to environment cleanliness (Masrifah, 2013). Clean body is related to an individual's purity measured by the cleanliness from big impurity (hadas besar) and small impurity (hadas kecil), while clean environment pertains to the beauty measured from the environment regularity and tidiness.

Environment cleanliness is an environment's beauty free from scattered-around and unmanaged rubbish. Therefore, rubbish management and environment arrangement get special attention in Islam. It is as mentioned in hadits retold by Tirmidi: "Actually Allah is good and loves goodness, clean and loves cleanliness, precious and loves preciousness. Therefore, clean your environment, please" (Tirmidi, 2013).

Unmanaged and haphazardly disposed rubbish can harm ourselves and others (Muslim, 2015). Rubbish disposal in the edge of street, for example, in addition to generating odor, can also result in disease. Moreover, rubbish disposal in the river is very hazardous as it can obstruct the river flow and result in flood. Therefore, Islam prohibit it communities from doing anything harmful to themselves and others as mentioned in hadits retold by 
Ahmad, Baihaqi, Hakim, and Ibnu Majah, as follows: "may not be harmful to self and others" (Nawawi, 2007).

The incidence of natural disaster such as flood in big cities is more due to human deed. Those with limited land prefer disposing rubbish in drainage channel to processing it. It of course leads to the obstructed river flow that can cause flood. In addition, the rubbish pile can result in climate change as well. It is because the rubbish pile leaved too long can produce methane. The increase in methane volume can raise the earth temperature or called global warming. This condition has been depicted in Quran Surrah ar-Rum verse 41 stating that the damage on the land and on the sea is due to human deed, in order that they can feel the consequence of their deed and in order they get back into the right way.

Meanwhile, much rubbish of residual human activity disposed still has selling value (Muslim, 2015). The presence of rubbish collectors (pemulung) who collect and sort rubbish as their livelihood proves that those goods are still usable. Disposing the still usable goods is lavish (waste). Islam prohibits its adherents from performing waste as explained in Qur'an Surrah Al Isro verse 27 and Al-An'am verse 41. Considering the understanding on these verses, Islam prohibits disposing rubbish from the residual activity that is still usable.

In fact, nearly all rubbishes of residual human activity are usable. Paper rubbish with all of its types, plastic rubbish with all of its type, glass rubbish and with all of its size, can, aluminum, and etc can be recycled (Muslim, 2015). Therefore, those rubbishes may not be disposed, as it still reusable. In addition, the disposal of plastic, paper rubbishes and similar or called non-organic rubbish into ground is of course harmful to the ground animals' life, because those animals need food to live. Meanwhile, their habitat is replete with indecomposable rubbish piles that cannot be the source of food (Majlis Ulama Indonesia, 2014).

Therefore, an assumption that rubbish is repugnant thing that should be disposed or removed is a wrong one from religion, environment and social aspects (Al-Anwari, 2014). This assumption should be corrected by conducting socialization or education about the correct rubbish management to the society. It is recalling the condition of increasingly accumulating rubbish due to the community's misunderstanding and inadequate consciousness of managing rubbish.

Socialization according to Hirzi et al. (2014) is the process of expressing idea or transferring habit from development communicator to the public, while according to Nasution (1989), socialization is a non-formal education effort intended to invite people to be aware of and willing to receive and to apply an innovation. Innovation intended in this case is an idea about technique of processing (managing) rubbish with economic and worship values to change the community's habit of disposing rubbish into that of managing and processing rubbish.

For the socialization to run effectively and to be fruitful, according to Rogers (1983), development communicator should consider four important things: firstly, innovation, that is, idea, action, or goods considered as new by development communicator. In this case, it is the novelty of innovation regarding religion values becoming the rubbish management material to build community's consciousness. Secondly, communication channel is the media to deliver innovation message from development communicator to the community (public), for example, face-to-face meeting by observing directly the correct rubbish processing in the field. Thirdly, period is the process of innovation acceptance from an individual beginning to know through an individual deciding to accept or decline it. Fourthly, social system is the set of functionally different units tied in the cooperation to solve problem in the attempt of achieving the mutual objectives.

In addition to the four factors above, Mardikanto (2010) mentioned that the successful innovation is also determined by communicator and beneficiary. From communicator side, a communicator should have credibility and good communication skill. Therefore, communicator is required to master interpersonal communication techniques, group communication, and public communication that can attract the listeners' attention (Nasution, 1989).

From beneficiary sides, the selection of beneficiaries highly determines an innovation. Rogers and Shoemaker (1971) suggests that every community group is divided into five by its speed in accepting innovation: $2.5 \%$ pioneer, $13.5 \%$ forerunner, $34 \%$ early adherent, $13.5 \%$ slow adherent, and $2.5 \%$ unchanging groups. Considering Rogers' perspective, the selection of beneficiaries (socialization participants) should be done thoroughly and precisely. Therefore, Lionberger (1960) provided criteria in selecting the participants of socialization in order to be successful completely. Those criteria include: firstly, business scale. The wider the scale of individual's business, the more quickly they accept innovation, because in addition to have a good economic ability, they also have broad knowledge and experience. Secondly, it is age. The older the individual, the more slowly is his/her acceptance to innovation and he/she tends to do routine activities only. Thirdly, it is participation level. Those participating actively in community activities will accept innovation more quickly than the passive ones. 
Fourthly, it is gender. Women tend to accept innovation more easily than the men do.

\section{Method}

This research was conducted using phenomenological qualitative approach. It means that the author attempted to understand the social phenomena related to community behavior in dealing with rubbish problem by describing it qualitatively. The reasons of this approach use are: firstly, it can be the source of more in-depth description and explanation. Secondly, it can build a closer relationship between author and informants becoming the target of study. Thirdly, it gives the author the opportunity of expressing a chronology of social events, assessing, and explaining about causal relationship occurring in local event. Fourthly, it facilitates the author in answering the question posed (Muslim, 2014).

The main informant in this research was those who have ever gotten socialization about rubbish management from PSM "Permata", while the supporting informant was the executor of rubbish management socialization from PSM "Permata". The informants were selected using snowball sampling technique. The number of main and supporting informants was determined based on the saturation of information obtained (Moleong, 2006). It means that new information expected to result from new informant is not obtained, the sampling was ended. The data was collected through observation, interview, and documentation. Data validation was carried out using triangulation technique, and technique of analyzing data used was an interactive model of analysis from Miles and Huberman (1984).

\section{Result}

\subsection{PSM "Permata" at a glance}

Pemata is a non-government organization operated in environment conservation sector. This institution has been established on February 5, 2012 based on the apprehension of society leaders in Pakem Tamanmartani Kalasan Sleman with the scattered rubbish in rice farm, garden, and street edge. The strong will to clean the environment from scattered rubbish encourages the society leaders to learn about managing rubbish correctly in Sukunan and Serut Hamlets. Tri Setyastomo, as the Hamlet Head of Pakem, said that:

During hamlet meeting, some people proposed to remove the rubbish piling in the entrance gate into hamlet because it smells not good and is dirty. However, where will be the rubbish removed? We have no solution to this, as there is no place to accommodate it. In addition, some people dispose rubbish to irrigation channel and it enters into the rice farmland. Considering the complicatedness in finding the solution, there is an idea to conduct comparative study on the areas successfully dealing with the rubbish problem. Then, a comparative study is decided to conduct, because some participants of meeting have known the area successfully managing rubbish well: Sukunan and Serut hamlets.

The comparative study conducted by these society leaders is fruitful, as it generates collective consciousness of the existence of rubbish. Rubbish, in fact, is not residual goods that should be removed, disposed, or annihilated, but it is a salable goods that can be processed and yield money. This consciousness growing collectively facilitates the organization of community particularly in dealing with the rubbish problem existing in Pakem Hamlet. Therefore, equipment or infrastructure needed in rubbish management in Pakem Hamlet is obtained through community self-help, rather than from government's or outsider's help.

Collective consciousness obtained from the result of comparative study in fact affects widely not only how to manage rubbish correctly, but also the wish to build Pakem Village the model hamlet and learning place or comparative study to manage rubbish for other hamlets. Since then, Pakem Hamlet settled itself by constructing a clean and healthy environment to welcome the guests who will expectedly come. Tree planting along the hamlet road, sumur resapan development, biopore development, and water source maintenance are the examples of program held to beautify the hamlet appearance. Therefore, it is unsurprising that on November 14, 2013, this village achieved two awards: first champion in Clean and Healthy Environment competition and second champion in Clean and Healthy Living Behavior competition. On June 25, 2014, it achieved an award as the first champion of environment rescuer, and on December 17, 2014 it achieved an award as the first champion in Climate Village competition from Sleman Regency.

The wish to make Pakem Hamlet the place for learning or comparative study for other hamlet compels the administrators of Permata to learn to be guest guide, presenter, and to organize the attractive rubbish management material different from that in other places. In addition, it compels the administrators of Permata to promote this hamlet through various media in order to be known by the public.

The attempt taken by Permata is not in vain. Since June 2012, the guests who want to learn about rubbish management begin to come. The first guest is the students of Islam Community Development Department 
conducting orientation study on the rubbish management. They were followed with the guests from some hamlets doing the similar activity. Since 2014, Permata has been trusted by Living Environment Office of Sleman Regency to be the place where the socialization of rubbish management is held for the hamlets existing in Sleman Regency area. The Living Environment Office of Sleman Regency's trust in Permata suggests that Permata is recognized as the institution with competency of socializing the rubbish management.

\subsection{Technique of Socializing Rubbish Management}

The socialization of rubbish management conducted by Permata consists of two models: visiting and visited. Visiting model is conducted when the participants of socialization invite Permata to be present in the place specified by participants. Meanwhile, visited model is conducted when the participants of socialization come to Permata Secretariat. In the visited model, socialization technique is conducted with the chronology from lecturing about rubbish management, observing the community practicing managing rubbish, and ending with discussion about anything not understood, while in the visiting model, socialization technique is conducted with lecturing and discussion only, without observing directly the community practicing managing rubbish. The detail of rubbish management socialization implementation using visited model is as follows:

Firstly, the participants are assembled in the mosque to obtain explanation about how to manage rubbish correctly. Here, Permata Team presents material through visual aid and oral explanation interactively. Here is the content of socialization material delivered:

First of all, presenter (someone designated by Permata Team) shows picture of rubbish pile. Then, the participants are asked for their opinion about the real condition. For example, how if the rubbish pile like this exists in the participants' land.
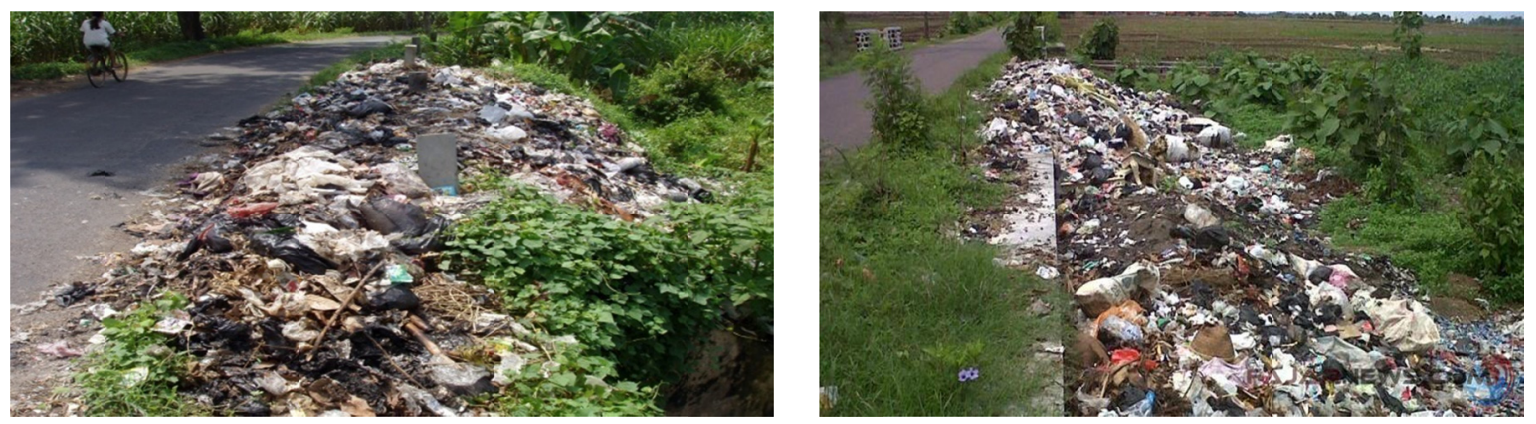

Figure 1. The pile of rubbish disposed by irresponsible people

After the participants reply with the certainly predictable answer, that is, dislike, the presenter continue his/her question "If you feel dislike such the pile of rubbish, where will you dispose the rubbish". The participants are compelled to answer, and the answer is predictable: in empty land, street edge, river bank, or rubbish disposal service. When the participants' answer is "disposed in the empty land", the presenter will reverse the argumentation with the question "how if the empty land is yours". On average, the participants answer that they will be discontented and angry when someone disposes rubbish in their land. Then the presenter concludes, "If it does so, you are selfish. It means that you are willing to dispose rubbish in others' land, but you angry when your land is used as rubbish disposal place. It indicates that whoever having the land used as the place to dispose rubbish must be angry". Similarly, when the participants answer "disposed into the river bank", the presenter will express similar argumentation, that the rubbish will enter into the rice farmland or obstruct the river flow. How if the rice farmland into which the rubbish enters is yours? The reaction must be "you will be angry".

The angry one will usually express their anger in something not good. For example, the angry people will not express their anger directly to those they are angry with, so that they will pray for their badness. The angry people whose land is used as rubbish disposal place without their knowledge equals to those experiencing cruelty (terdholimi). Meanwhile, the pray of those experiencing cruelty is the granted one. Here are the forms of upsetting expression from the people whose land is used for disposing rubbish without their permission or knowledge:

The presenter read the writing included in the picture one by one, from "Whoever disposing rubbish will die and go to hell, his brain will be stiffed and his livelihood will be inhibited", "Oh Allah, please take the soul of those disposing rubbish here off", and "Whoever disposing rubbish here will die due to traffic accident", while making the participants aware of not disposing rubbish haphazardly. The writing above, in addition to be pray, show that the owner of land used for disposing rubbish is very angry. 

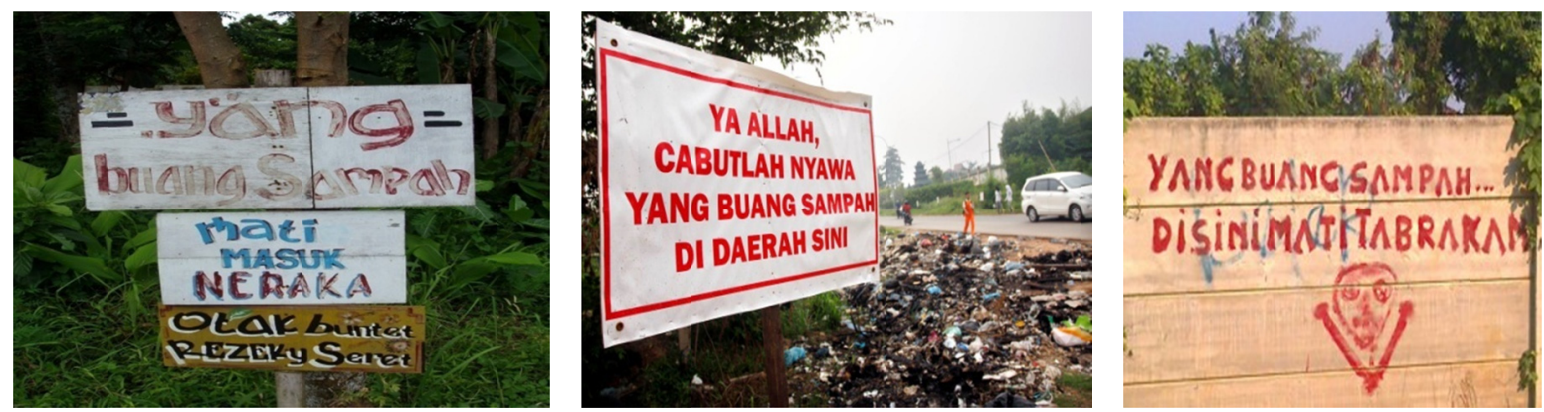

Figure 2. the forms of upsetting expression from the people whose land to rubbish disposer

Furthermore, the presenter shows the picture of rubbish burning in figure 3, and asks the participants whether or not the rubbish burning becomes a solution. After the participants answer, the presenter explains that rubbish burning can result in various diseases that can affect everyone breathing the air mixed with smoke from rubbish burning. It means that rubbish burning can affect negatively those who burning rubbish and others.

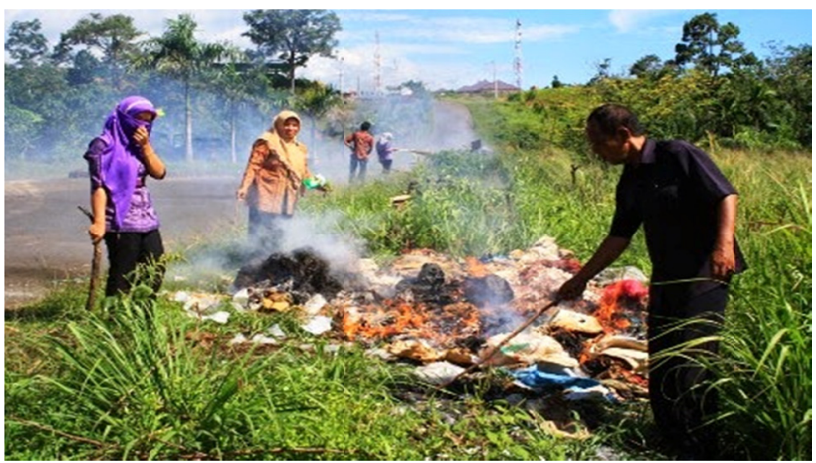

Figure 3. Removing rubbish by burning it

Then, the presenter asks about the law of disposing rubbish to the participants based on the negative effect of rubbish disposal in others' land or in river bank and negative effect of rubbish burning as aforementioned. After the participants answer this question, the presenter concludes that the law of disposing or burning rubbish is proscribed (illicit or haram). It is based on the fatwa MUI Number 47 of 2014.

After the participants realize that disposing rubbish is prohibited by religion, the presenter continues his explanation about how to process the rubbish with economic and worship values. Regarding this, see the author's article entitled “A Model of Shodaqoh Based Waste Management" in journal of Environmental Management and Sustainable Development in http://dx.doi.org/10.5296/emsd.v4i1.7300.

Secondly, the participants of socialization are shown with the practice of managing rubbish (waste) conducted by Pakem hamlet people as explained in the mosque. The participants of socialization are guided by Permata Team to see, question, and discuss well with the community directly and with the Permata Team about how to manage rubbish, the problem occurring, and solution to solve the problem.

Thirdly, the participants of socialization meet the presenter again to confirm their findings in the field. In addition, this meeting is intended to discuss further anything not understood by the participants. The socialization of rubbish management event is ended when there is no more problem conveyed by the participants to the presenter.

\subsection{The effect of Socialization on Community Behavior in Managing Rubbish}

The finding about the effect of rubbish management socialization based on fatwa MUI Number 47 of 2014 on the community behavior in dealing with rubbish problem shows varying results. On the one hand, some people are conscious directly and willing to manage rubbish in their residence. It is just like what suggested by Mujiburrahman who lives in Krajan as follows:

"Having attended the socialization in Pakem Hamlet, our people agree to manage rubbish just like what the Pakem Hamlet people did. The consciousness of managing rubbish arises mutually because we deliberately invited as many as people to learn managing the rubbish in Pakem Hamlet. ..... think what generate the people's consciousness in the socialization are the elaboration of empirical data and the religious analysis. 
The socialization can really touch and change the people's mindset".

In similar vein, Halim said that Dukuh people become conscious and willing to manage rubbish after attending the socialization of rubbish management in PSM "Permata", as expressed below:

"Actually Dukuh people have long managed rubbish with reduce, reuse, and recycle method. But it has not been like what occurs today. Formerly it was difficulty to build the people's consciousness and some people remained to dispose rubbish in the garden, despite socialization about how to manage rubbish correctly. .....Collective consciousness started to be established after Dukuh people attended socialization in PSM "Permata". Initially only society leaders learnt in PSM "Pemata". Thereafter, PSM "Permata" was invited to come to Dukuh to socialize to all people in pengajian umum (general recitation) activity. .....I think the material of socialization delivered by PSM "Permata" is indeed appropriate to generate Islam communities' consciousness in treating rubbish problem".

On the other hand, some people are consciousness after attending the socialization and trying to manage rubbish in their residence, but it runs less smoothly because of limited facility and inadequate support from government. It is like what suggested by Waluyo managing rubbish in Tlukan:

We actually still manage rubbish vigorously. The people's consciousness has been good here, particularly those who have ever attended socialization in PSM "Permata". But the administrators' spirit decreases. The administrators find difficulty in selling the sorted rubbish and they are confused in looking for the solution. They ask the Village Government for the solution, but they are recommended to Living Environment Agency. In Living Environment Agency, they are recommended to contact the Regency's rubbish management association. Because they find no solution, finally they sell the rubbish to collector with very cheap price. Because the result of rubbish is not comparable to the hard work, the administrators manage rubbish more lazily.

Similarly, the rubbish processor in Kliwonan finds difficulty in looking for temporary rubbish accommodation place. Setyawati reveals the problem occurring during managing rubbish in Kliwonan as follows:

Here, managing rubbish is troublesome. It is perhaps unlike in other places, such as Pakem. The trouble here is related to no place available to be used as temporary accommodation place. The administrators have contacted the one with wide land or to look for village cash land to be the temporary accommodation place, but their effort has not been fruitful. Finally, the administrators take the rubbish from houses to be sold. It also generates some risks. One day, when the rubbish has been collected, the buyer does not come. This condition makes the administrators manage the rubbish less vigorously.

Meanwhile, some people admit that they are conscious about it, but have never managed the rubbish. It is because no one or leader organizing the rubbish management. They are invited to learn managing rubbish in PSM "Permata" by outsiders conducting service to society in their residence. But, unfortunately, when the service to society ends, they are left and the program is never followed-up. It is like what Suhartini living in Kembangarum suggests:

On average, women here realize that disposing rubbish is illicit just like what has been explained in the socialization in masjid Pakem. But, what should we do? No youth or man is willing to organize it. They have not been conscious, because they have never attended the socialization. The socialization held by the college students in fact invited the women only. Perhaps the youth and men were not invited, or the participants were limited to 30 persons only, so that only women were invited.

Similarly, Winarsih living in Kawedan suggests that:

I am aware and I think my friends who have ever attended the socialization in Pakem are also aware. But no one has initiated it, because no activator exists. This activity will not work when relying on women only, while the youths and men are passive. They have never gotten socialization like the women. The college students conducting KKN (community service) are expected to come here again, to give socialization to the youth and men, in order to give them equal understanding so that we can move together.

Finally, some other people are not aware of and do not care about the rubbish problem even after attending the socialization. They even do not understand the end objective of rubbish management socialization. They attend the socialization because they are asked to attend compulsively to fulfill the quota of participants because the core participants could not come. Some others attend the socialization because they have kinship with the one assigned to look for participants recalling that the participants present are given pocket money and transporting money. In addition, some people attended only to do their superior's instruction. It is suggested by Catur as the health officer in public health center (puskesmas) assigned to coordinate the implementation of rubbish 
management socialization in Kalasan Sub District as follows:

The areas where the rubbish management has not run yet indeed deal with this problem not seriously during the socialization. For example, the participants involved were unemployed women, the elderly, unemployed youths, and even the hamlet head designated to coordinate his people did not implement it seriously, they only undertook their superior's instruction, so that the participants selected are not as expected. Meanwhile, we from puskesmas have specified the criteria of who can be included into the socialization participants.

It is justified by Mrs. Santo who live in Bogem Hamlet, admitting that she have gotten socialization about rubbish management from PSM "Permata" in local mosque, and stating as follows:

I have ever gotten socialization about rubbish management in mosque. At that time, it was concomitant with the schedule of women routine recitation (pengajian rutin ibu-ibu). The participants are all adult women. As the intermezzo, amid the recitation, rubbish management is presented by a presenter coming from Pakem. The material delivered is very attractive and real, just like what I face daily. .....That is apparently the village or sub district program, as after socialization there have been consumption grant from puskesmas through head of hamlet. .....But it has not been followed up until now. The rubbish management has not run yet, because there is no further explanation from head of hamlet about the follow-up action after the socialization.

\section{Discussion}

The successful socialization of rubbish management indicated with the consciousness and the change of community behavior in managing rubbish is affected by such factors as the appropriate selection of socialization participants. The case in Dukuh, as suggested by Halim, proves that the society leaders who have been aware of the importance of managing rubbish begin to transmit anxiously their knowledge to their family and neighbor. However, due to limited experience, they have not been able to transfer the knowledge they obtain, so that they attempt to invite and to facilitate PSM "Permata" Team to socialize to their family and neighbor through recitation forum. After the consciousness has grown in all classes of society, the rubbish management in Dukuh runs smoothly. It is also true in Krajan, as suggested by Mujiburrahman. It is consistent with Rogers and Shoemaker (1971) stating that the selection of beneficiaries should be done thoroughly and precisely, because the speed of innovation acceptance is varying in different people: $25 \%$ in pioneer, $13.5 \%$ in forerunner, $34 \%$ in early adherent, $13.5 \%$ in slow adherent, and 2.5\% in unchanging groups. Meanwhile, the socialization conducted with women only as the participants is in fact not fruitful maximally, for example in Kembangarum, Kawedan, and Bogem. Therefore, the criteria suggested by Lionberger (1960) in selecting the participant of socialization should be considered.

In addition to the participant selection appropriateness, another important factor determining the successful rubbish management socialization is the finding of people that can organize activity. The one like Halim is the youth active in the community activity, just like Mujiburrahman. Both of them can organize community, because they participate actively in this community activity. It is in line with Lionberger's statement (1960) that those active in community activity tend to accept innovation more quickly and can organize the community than the passive ones. In community empowerment theory, those organizing empowerment activity should derive from internal community rather than from outsiders (Ife, 1996). The indicator of successful community empowerment is the emergence of community's consciousness and ability of implementing the program independently, not dependent on outsiders (Muslim, 2012). Therefore, the failure of rubbish management socialization existing in incorrect facilitation program is due to the facilitation program making the community dependent on the facilitator (college students conducting community service).

The participants' readiness in receiving complete information about the objective of socialization also determines the successful rubbish management socialization. The appearance of collective consciousness about the importance of managing rubbish growing in Krajan, Dukuh, and some other places is because the participants of socialization have known the objective to be achieved from the beginning, or before the socialization is conducted. It is in line with innovation adoption theory from Rogers (1983) stating that there are four important problems to be considered to make the innovation socialization run effectively: period or the participants' readiness in receiving information on innovation from the time they know through decide to receive or to decline it. Considering this theory, the failure of rubbish management socialization occurring in Bogem is because the participants of socialization do not receive information completely. The participants of socialization consist of women affiliated with the recitation community are not informed about the objective of rubbish management socialization and its implementation from the beginning.

Another factor affecting the successful socialization is government support. The cases in Tlukan and Kliwonan 
prove that government supports the program inadequately. Not all rubbish processor (organizer) can sell the sorted rubbish to the collector, because sometimes the collector is not ready to buy the rubbish during rubbish abundance and the price decreases. Such the condition of course makes the rubbish organizer confused and frustrated, moreover when the rubbish accommodation place is limited and cannot accommodate new rubbish. Therefore, the government support is very desirable, for example by providing the land for temporary accommodation place or by helping find the buyers for the sorted rubbish. In many cases, government support to rubbish organizer is still in the form of rubbish transportation and disposal to the final disposal place, not leading to looking for economic value-based solution (Utami et al., 2008).

The factor mostly affecting the successful socialization of rubbish management based on fatwa MUI is the material of socialization emphasizing on economic and religious value approach. The people of Sleman Regency are majority Muslims. They live largely in rural areas and in urban areas. Those living in rural and suburban areas hold strongly on cultural tradition (Ruyadi, 2010). Therefore, their loyalty to undertaking religious instruction and keeping far away from religious prohibition is still held on tightly. It is this condition that makes the implementation of rubbish management socialization based on fatwa MUI capable of generating and building the consciousness among the participants of socialization, as suggested by some informants above. The material of rubbish management based on fatwa MUI is an innovation. Rogers (1983) stated that for the implementation of socialization to run effectively and efficiently, the development communicator should make innovation. Innovation, according to Mardikanto (2010), is new ideas, new practices, or objects that can be considered as something new by the community as the target of development. The novelty of rubbish management material based on fatwa MUI lies on the combination of economic value-based and religious value-based rubbish management materials.

\section{Conclusion}

The socialization of rubbish management based on fatwa MUI Number 47 of 2014 can build consciousness and change the community behavior collectively in dealing with rubbish problem, when (1) the participants of socialization are selected considering the representativeness of all community elements, (2) there are volunteers from the community who were willing to organize, (3) the participants are given information completely about the objective of socialization, (4) there is government support to the community conducting rubbish management activity, and (5) the material of socialization is taken for granted (considered as true) by the participants of socialization, so that they assume that ignoring the truth amounts to breaking the religion tenet.

This finding theoretically can be the conceptual reference for the practitioners of community empowerment in building consciousness and in changing the community behavior, particularly in dealing with the rubbish problem. Practically, this finding is expected to be the guideline and appropriate solution to the practitioners of community development in dealing with rubbish problem.

\section{References}

Al-Anwari, A. M. (2014). Strategi Pembentukan Karakter Peduli Lingkungan di Sekolah Adiwiyata Mandiri. Ta'dib, 19(2), 227-252. Retrieved from http://jurnal.radenfatah.ac.id/index.php/tadib/article/view/16/11

Chaesfa, Y., \& Pandjaitan, N. K. (2013). Women's Perception of Environmental and Waste Management Participation in Household: the Case of Babakan Village, District Dramaga, Bogor Regency, West Java Province. Sodality: Jurnal Sosiologi pedesaan, 1(2), 193-212. Retrieved from http://journal.ipb.ac.id/index.php/sodality/article/view/9401/7366

Hirzi, A. T., Umar, T. M., Hasbiansyah, O., Iskandar, D., Hanifah, H. Q., \& Ariditha, Y. (2014). Sosialisasi dan Aplikasi Pengelolaan Sampah Organik di Desa Cikole Kecamatan Lembang Kabupaten Bandung Barat. Prosiding Seminar Nasional dan PKM Sosial, Ekonomi, dan Humaniora, 4(1), 229-234. Retrieved from http://proceeding.unisba.ac.id/index.php/sosial/article/view/156

Ife, J. (1996). Community Development: Creating Community Alternative Vision, Analysis and Practice. Melbourne: Longman.

Ittiravivongs, A. (2012). Recycling as Habitual Behavior: the Impact of Habit on Household Waste Recycling Behavior in Thailand. Asian Social Science, 8(6), 74-81. http://dx.doi.org/10.5539/ass.v8n6p74.

Lionberger, H. F. (1960). Adoption of New Ideas and Practices. Iowa: the Iowa State University Press.

Majlis Ulama Indonesia. (2014). Fatwa Majlis Ulama Indonesia Nomor 47 Tahun 2014 tentang Pengelolaan Sampah Untuk Mencegah Kerusakan Lingkungan. Retrieved from http://crpg.info/mwiki/images/9/94/\%27 Sudirman_Asun\%27_via_Water_JakartaWed\%2C_14_Jan_2015_041713_\%2B0000_\%28UTC\%29.pdf 
Mardikanto, T. (2010). Komunikasi Pembangunan: Acuan Bagi Akademisi, Praktisi, dan Peminat Komunikasi Pembangunan. Surakarta: Program Studi Pemberdayaan Masyarakat Program Pascasarjana Universitas Sebelas Maret.

Masrifah, S. (2013). Peranan Kebersihan Lingkungan Sekolah Dalam Mendukung Aktivitas Belajar Siswa di Madrasah Ibtidaiyah al-Ihsan Banjarwungu Kecamatan Tarik Sidoarjo. (Undergraduate's thesis) Universitas Islam Negeri Sunan Ampel, Surabaya. Retrieved from http://digilib.uinsby.ac.id/11280/

Miles, H. B., \& Huberman, A. M. (1984). Qualitative Data Analyse, a Source Book of New Methods. Sage.

Moleong, L. J. (2006). Metodologi Penelitian Kualitatif. Bandung: Remaja Rosdakarya.

Mulasari, S. A. (2012). Hubungan Tingkat Pengetahuan Dan Sikap Terhadap Perilaku Masyarakat Dalam Mengolah Sampah Di Dusun Padukuhan Desa Sidokarto Kecamatan Godean Kabupaten Sleman Yogyakarta. KesMas, 6(3), 144-211. http://dx.doi.org/10.12928/kesmas.v6i3.1055

Muslim, A. (2012). Dasar-Dasar Pengembangan Masyarakat. Yogyakarta: Samudra Biru.

Muslim, A. (2015). A Model of Shodaqoh-Based Waste Management. Journal of Environmental Management and Sustainable Development, 4(1), 164-179. http://dx.doi.org/10.5296/emsd.v4i1.7300

Muslim, A. (2014). Model Pemberdayaan Ekonomi Masyarakat Miskin Perkotaan Berbasis Tanggung Jawab Sosial Masjid, (Unpublished Doctoral Dissertation). Universitas Sebelas Maret, Surakarta.

Nasution, Z. (1989). Prinsip-prinsip Komunikasi Untuk Penyuluhan. Fakultas Ekonomi Universitas Indonesia.

Nawawi, I. (2007). Hadits Arba 'in. Jakarta: Gema Insani.

Nugraha, W. D., Suri, D. A., \& Syafrudin. (2007). Studi Potensi Pemanfaatan Nilai Ekonomi Sampah Anorganik Melalui Konsep Daur Ulang Dalam Rangka Optimalisasi Pengelolaan Sampah. Teknik, 28(1), 9-20. Retrieved from http://ejournal.undip.ac.id/index.php/teknik/article/view/2077

Nuzuli, O. F., Gani, Y. A., Pratiwi, R. N., Hanafi, I., \& Fitrianto, A. (2015). Policy Implementation of Local Communities Development-Based Waste Management in Banjarbaru, South Kalimantan, Indonesia. Asian Social Science, 11(18), 279-287. http://dx.doi.org/10.5539/ass.v11n18p279

Riyadi, S. (2015). Reiventing Bank Sampah: Optimalisasi Nilai Ekonomis Limbah Berbasis Pengelolaan Komunal Terintegrasi. Al-Amwal, 7(2), 205-215. Retrieved from http://syekhnurjati.ac.id/jurnal/index. $\mathrm{php} / \mathrm{amwal} / \mathrm{article} / \mathrm{view} / 208$

Rogers, E. M. (1983). Diffusion of Innovations. London: The Free Press.

Rogers, E. M., \& Shoemaker, F. F. (1971). Communication of Inovation. New York: Free Press.

Ruyadi, Y. (2010). Model Pendidikan Karakter Berbasis Kearifan Lokal: Penelitian Terhadap Masyarakat Adat Kampung Benda Kerep Cirebon Provinsi Jawa Barat Untuk Pengembangan Pendidikan Karakter di Sekolah. Proceedings of the 4th International Conference on Teacher Education, 576-594.

Setyowati, E. (2015). Pemberdayaan Ibu-Ibu Rumah Tangga Muslimah Dalam Mengelola Sampah Melalui E-Media Berwawasan Sains Teknologi. INFERENSI: Jurnal Penelitian Sosial Keagamaan, 9(1), 69-94. Retrieved from http://inferensi.iainsalatiga.ac.id/index.php/inferensi/article/view/295

Tirmidzi, A. I. M. (2013). Ensiklopedia Hadits 6: Jami'at-Tirmidzi. Jakarta: Almahira.

Undang-Undang RI. (2008). Undang-Undang Republik Indonesia Nomor 18 Tahun 2008 tentang Pengelolaan Sampah. Retrieved from http://www.menlh.go.id/DATA/UU18-2008.pdf

Utami, B. D., Indrasti, N. S., \& Dharmawan, A. H. (2008). Pengelolaan Sampah Rumah Tangga Berbasis Komunitas: Teladan dari Dua Komunitas di Sleman dan Jakarta Selatan. Sodality: Jurnal Trandisiplin Sosiologi, Komunikasi, dan Ekologi Manusia, 2(1), 49-68. Retrieved from http://journal.ipb.ac.id/index.php/sodality/article/view/5893

Yudistira, H. (2013). Pola Perilaku Membuang Sampah Masyarakat Kampung Sangir Kelurahan Titiwungen Selatan Di Daerah Aliran Sungai Sario. Jurnal Holistik, 6(11), 1-14. Retrieved from https://ejournal.unsrat.ac.id/index.php/holistik/article/view/1730

\section{Copyrights}

Copyright for this article is retained by the author(s), with first publication rights granted to the journal.

This is an open-access article distributed under the terms and conditions of the Creative Commons Attribution license (http://creativecommons.org/licenses/by/4.0/). 